University of Louisville

ThinkIR: The University of Louisville's Institutional Repository

\title{
Making theatre special without special effects : You better sit down : tales from my parents' divorce.
}

Anna Neikirk

University of Louisville

Follow this and additional works at: https://ir.library.louisville.edu/honors

Part of the Theatre and Performance Studies Commons

\section{Recommended Citation}

Neikirk, Anna, "Making theatre special without special effects : You better sit down : tales from my parents' divorce." (2015). College of Arts \& Sciences Senior Honors Theses. Paper 46.

http://doi.org/10.18297/honors/46

This Senior Honors Thesis is brought to you for free and open access by the College of Arts \& Sciences at ThinkIR: The University of Louisville's Institutional Repository. It has been accepted for inclusion in College of Arts \& Sciences Senior Honors Theses by an authorized administrator of ThinkIR: The University of Louisville's Institutional Repository. This title appears here courtesy of the author, who has retained all other copyrights. For more information, please contact thinkir@louisville.edu. 


\section{Making Theatre Special Without Special Effects \\ You Better Sit Down: Tales from My Parents' Divorce}

By:

Anna Neikirk

Submitted in partial fulfillment of the requirements of Graduation summa cum laude

University of Louisville

May 2015 


\section{Table of Contents}

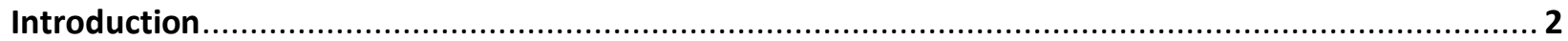

Minimalism: Samuel Beckett and Jerzy Grotowski..................................................................... 4

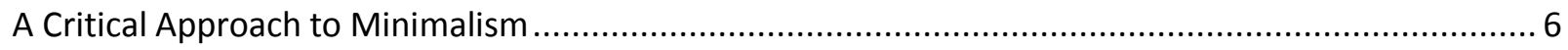

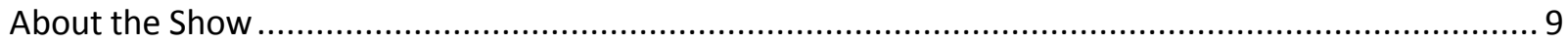

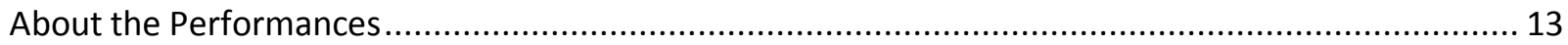

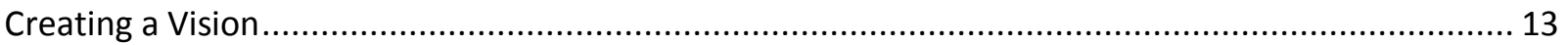

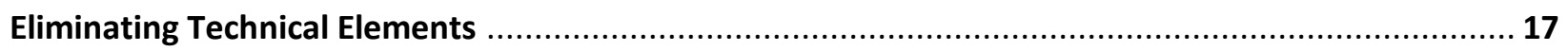

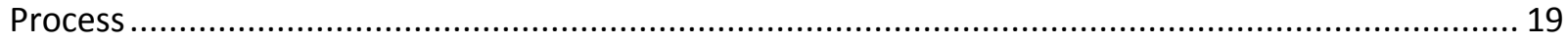

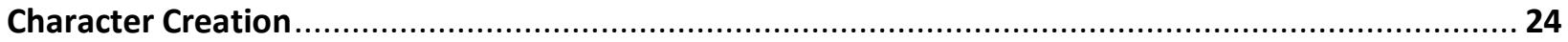

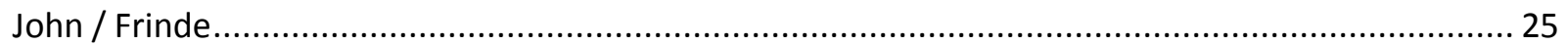

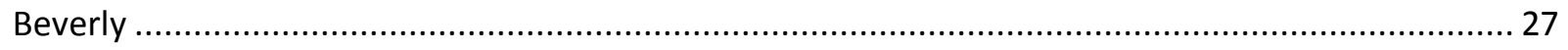

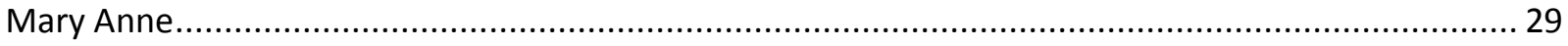

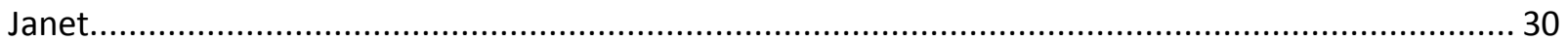

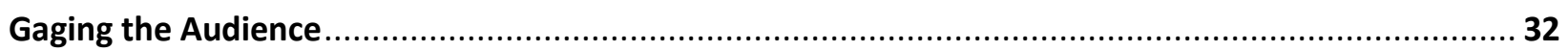

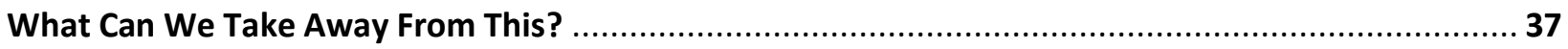

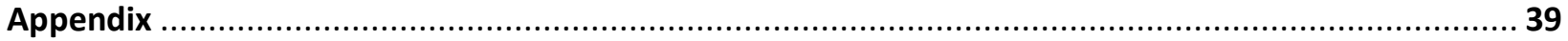

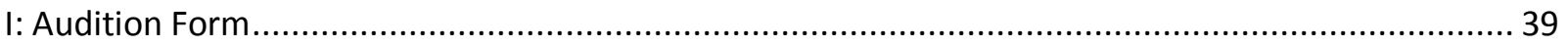

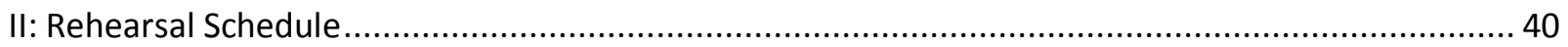

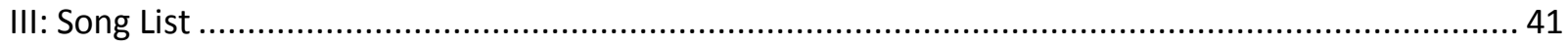

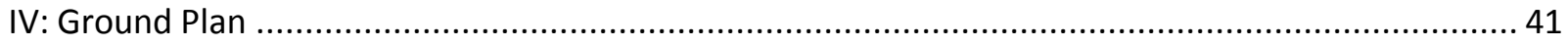

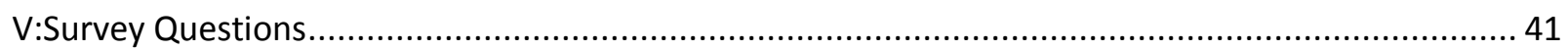

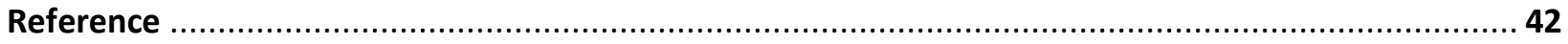




\section{Chapter I: Introduction}

On any given day, hundreds of thousands of people throughout the world go to see a play or other type of theatre event. Theatre and performance are ingrained in the human experience from the origin of civilizations when ritual performance, role playing, storytelling, and ceremony laid the foundations for performance (Wilson 3). Being so deeply rooted in the human experience, theater also reflects humankind's circumstances and changes. Primitive when humans were primitive, theater advanced as civilization advanced. Today, commercial theatre has become a multi-billion dollar industry - just as other parts of culture and commerce have done the same.

But where does all that money go and to what end? Consider Spider-Man: Turn Off the Dark. Produced on Broadway in 2011, Spider-Man cost a reported \$75 million; more than double the cost of any previous Broadway production. Nine million dollars alone was spent on sets and costumes (Flynn and Healy). No doubt, shows like this attract audiences. The Broadway League reports that Spider-man alone was seen by over two million people in New York City. North American tours of other Broadway productions were seen by 13.8 million people in more than 200 cities in 2013-2014. This and other popular, budget-busting productions often utilize the latest in technological advances, like Spider-Man which used an audio system 50\% larger than any other Broadway production, the largest wireless system, and more than 2500 lighting fixtures (PRG). And it is not just Broadway; according to the "A Tale of Four Budgets", an average of more than $\$ 7500$ is spent on every 60-seat off-off Broadway production, and more than $\$ 1300$ of that is spent on scenic elements alone. 
Often, spectacle is the attraction. The first recorded use of onstage lighting was in 1545 , when lanterns and torches illuminated the actors and sets. Much has changed. Today, holograms are placing actors (O’Neil). How long before computers replace stage managers and programmers replace directors? The Guardian observed that "increasingly, the technology has become the show rather than in service of it" (Gardner). This was not always so. The ancient Greeks performed on bare stages, with natural scenery as their sets. Aristotle wrote in The Poetics that the least important element of good tragedy was spectacle. Yet, young people today are used to cellphones answering questions for them, children learning on IPads, and "apps" tracking their sleeping and eating patterns. Today's younger audiences are not used to seeing theatre on a bare Greek stage. The younger generations are expecting that since technology has been so integrated into their daily lives, art should integrate new technology also. Broadway and other theatres are ready with productions like Spider-Man to entice technology-laden audiences into their seats.

But has technology become the show? Have we lost what made theatre special from its inception? My project aims to answer this question. Separating theatre from the spectacle allows us as a society to have renewed hope that art and creativity can stand without technology and can make a lasting impact on the audience without exorbitant budgets.

Can minimizing the use of production elements (e.g. sets, props, costumes, lighting and sound) help connect audiences with the intellectual and emotional content of the play? For this project, I directed You Better Sit Down: Tales from My Parents' Divorce at the Slant Culture Theatre Festival as a production with minimal technical elements with the intention to evoke an emotional connection with the characters and their stories, and to stimulate the conversation about divorce in today's society. 


\section{Minimalism: Samuel Beckett and Jerzy Grotowski}

Minimalism is a style of Western art developed after World War II. In drama, the approach is most notably attributed to Samuel Beckett. Stanley Gontarski, an avid scholar of Beckett, calls Beckett's work the "intent of undoing" in his book of the same title. Samuel Beckett often reduced the length of the script, the number of characters, the action and biographical information all on the principle that "less is more" His characters lack complex human emotions. His dialogue is sharp and unembellished. (Xhonneux 2). In the essay, A Few Words About Minimalism, Johnathan Barth breaks down minimalism like that of Beckett into two components, the first, concerning writing style, word use, and sentence structure. The second involves a "minimalism of materials" by which he means a stripping down of characters, plot, action, design to reveal the necessary, the essential.

The script for Tales from My Parents' Divorce and my subsequent staging are consistent with portions of the definition of minimalism. The play has few characters, little physical action, and, in my staging, few technical elements. But Tales is written in a style that contrasts to Beckett's literary style of minimalism. Its dialogue isn't built with the staccato sentences found in a Beckett play and its characters are more emotive. That said, Tales is a play that lends itself to minimalism of materials, as defined by Barth. There is little overall plot, other than that four couples meet, marry, and split up; but each character's story is a variation on that plot, informed by the circumstances of that character's marriage and divorce. It seeks to recreate a series of conversations about marriage and divorce, with emotive acting intended to give one, as a member of the audience, the feeling that one is in each conversation. There is little action, being that the actors remain seated for nearly the entire show. It is an intimate play, with characters recounting their relationships and breakups, often in candid detail. Whereas in the style created 
by Beckett — which Bell lays out as an "artistic non-entity" (39) where plot, character, meaning, and subject are stripped down to almost nothing — the style in Tales focuses on the meaning. There's no attempt in Tales to strip away character, meaning, or even subject. The subject is divorce but romance, children, career, life choices, happiness or the lack of it, betrayal - all of those are subjects and their meaning is explored. There's nothing minimalist in the way the four characters are called on to describe their lives.

Where this production and minimalism do best coincide is staging. I employed Barth's minimalism in design since, as previously mentioned, this script centers around conversations, intimate conversations usually reserved for living rooms or other quite areas. If too much spectacle were forced on the material, its intimacy would be lost. In a review published in Theatre Journal, Martin Puchner looks at staging of three Beckett plays and one by Edward Albee at the Century Center for the Performing Arts. He contends that these productions "squeeze as much spectacle out of the text as possible," therefore negating the play's initial value. This could have happened with a production like Tales, if too much spectacle was forced on the material. The production may have lost its initial intent which was to help audiences begin looking at and discussing divorce in today's society.

My minimalist design aesthetic also draws from the stripped down aesthetic of Jerzy Grotowski and his "poor theatre." Poor Theatre developed in the late 1950s and was labeled "poor" because of its elimination of the theatricality and technologies of "rich" theatre in order to make the actor's voice and body movements central to the production. In these productions, only stationary light sources were used, music and sound effect was created by the actor. Costumes were common, everyday clothing. Grotowski wanted to investigate the actor-audience relationship. As he put it, "when the theatre confronts us with brutal situations where the life 
mask cracks and falls away, it can expose an intimate layer which returns us to common human truths" (Hodgson). Grotowski wanted to find what made theatre special and unique from film and television. "By gradually eliminating what proved superfluous," he found that theatre can exist "without make-up, without autonomic costume and scenography without a separate performance area, without lighting and sound effects etc. It cannot exist without the actorspectator relationship of perceptual, direct, 'live’ communion” (Grotowski 19). My staging borrowed from Grotowski the creation of a relationship between the actor and the audience. The space and material was so intimate that a connection could be made without the superfluous. Removing the "life-mask" as Grotowski calls it, or the superfluous, or the distraction from the character and their story, the audience is able to connect to common human truths. I wanted to take the premises of "poor theatre" and its impact on the audience and make it the focus of my approach to theatre of the $21^{\text {st }}$ century.

\section{A Critical Approach to Limiting Technology}

When looking at what Barth defined as "minimalism of materials" in today's society, one must look at the use of technology on the stage. The discussion of technology and the uses of technical elements in theatre is a lively one. Most critics and scholars agree that for a performance to be theatre it must involve "people witnessing other people in a physical space" (Acaroglu 1). Beyond that, the definition of what constitutes theatre and especially how theatre is changing is an open dialogue.

Scene designer, Thomas Leff, discusses in his article, Décor or Space: Architectural Stage Design and the Contemporary Theatre, architectural theatre and its place in contemporary stage design. In his view, design should be functional and aid in the movement and voice of the 
actor. He argues that simplicity of a stage does not restrict its expressiveness but directs the focus to the performer (69). He cites Edward Craig and his belief that today's designs have lost what they originally were, which was architecture. They have been corrupted by "a desire to decorate and please the eye". They have become visually self-indulgent (69). He calls for designers to bring theatre back to the artistic and intellectual respectability of other art forms. Leff's argument follows much of the same ideas Puchner had in his review of Beckett and Albee. It can be a mistake to try and squeeze the spectacle out of a piece, either to mask issues with the text or to please the eye. Shifting the aesthetic to make the actor the focus, like I did with Tales, is consistent with Leff's argument that design should be functional for the actor.

Similarly to how Leff believes that today's design aesthetics need to shift back to making the actor the focus, Aronson discusses in his article, Theatre Technologies and the Shifting Aesthetic, how the aesthetic has to shift to adapt to more technological audiences. Arnold Aronson supports the use of technology on today's stages, but emphasizes that what is important is how it is integrated into the production. Aronson argues that "it is possible that theatre has been altered so radically by technology and by aspects of popular culture... that we do not recognize it because we have failed to name it. If theatre is going to survive as a viable art form then we must find new structures for new audiences" (3). Technology, he continues, has the ability to change the way we view the world. Consider the perception of light. We live in a world where man-made structures block daylight outdoors and artificial light governs indoors. Commercial light reflects off buildings instead of the moon and stars making us often perceive night as brighter than day. These light-saturated audiences then do not bat an eyelash at one hundred intricately laced light cues in a theatre production. With technology as an expectation, designers and directors feel compelled to find new ways to excite audiences. Aronson proposes 
that theatre does not need to become a spectacle of gizmos and technology, but rather a new way of seeing. Our technological culture is shifting our aesthetic and theatre must employ ways to connect to its cyber audiences.

Aronson's argument supports my use of sound in Tales. The show used popular songs of the play's respective decades to shift between scenes and help denote the passage of time. Though there can be extensive technology associated with the use of sound, playing it on a laptop through speakers is not something audiences gawk at. I used the technology in a way to advance the movement of the script. Each day we hear music play through a radio. We may just recognize songs as top hits. But those top hits serve as a time capsule in a way; they can be used to let audiences know when and where the play is taking place. Also, due to the growing popularity of headphones, sound emitting from speakers is nothing new for audiences. The use of music as a fluid transition could be more accessible to audience members used to listening to music as they drive or work through the day. Sound can stand for a logical transition from point A to point B. And as Aronson suggests, that integration of technology can help my audience connect to the production.

In contrast to Aronson and Leff, Australian theatre artist, Gorkem Acaroglu, looks at how theatre must adapt its aesthetic and definition of theatre "presence" in our technology-driven societies. In his article, Cyborg Presence in Narrative Theatre, Acaroglu looks at performances that use holograms in roles originally reserved for live actors. He defines the term "cyborg theatre" as theatre that "uses existing and emerging technology not purely as a frame or an aesthetic scenic backdrop for projected images, but as a mutually dependent component of a larger complex of social, political and theatrical systems existing between the live and the technological”. Acaroglu looks at Marianne Weem's company, The Builder's Association, and 
how the company integrates media into its productions. Weem believes that the dialogue with the technology enhances the actor. Acaroglu critiques ideas that projections overpower actors and argues that it is the actors' experience with technology that determines whether or not they will be upstaged. An actor must "make present" the technology, connect to it, just as film actors once had to learn to connect to a camera instead of an audience. Acaroglu also attributes this process of connecting to media to people connecting through webcams. Though one's "audience" is not physically in the same space, a connection is made to the technological presence.

Acaroglu's approach to connecting with the holographic or media presence on stage is an interesting one. However, for a production like Tales it was important that audiences connect with the characters and their stories. The original production utilized a projection screen for which the script centered around. The actors then would interact with home videos or pictures projected on the screen. I wanted the audience to connect to the physical actor, not a mediaprojected one as Acaroglu suggests.

It is this evolving discussion about whether technology should or should not be incorporated into theatre that inspired my work with Tales from My Parents' Divorce. As others look to advance into the world of new technologies, I looked to retreat, to revisit some of the practices of minimalism and re-work them for the $21^{\text {st }}$ century. This ever-changing discussion of whether to retreat or to advance is a dialectic that will continue to influence the way theatre changes for future technological generations.

\section{About the Show}

You Better Sit Down: Tales from My Parents' Divorce was first developed in 2009 by the Civilians Theatre Troupe. The piece premiered at the Williamstown Theatre Festival in August 
2011 and made its New York debut at the Flea Theatre in April 2012. Written by Anne Kauffman, Janice Paran, Robbie Collier Sublett, Matthew Maher, Jennifer R. Morris, and Caitlin Miller, the original production was directed by Ms. Kauffman and featured the following cast:

- John and Frinde (dual role) - Matthew Maher

- Beverly- Jennifer R. Morris

- Mary Ann- Caitlin Miller

- Janet- Robbie Collier Sublett

The play, while meant to entertain, is at least equally intended to make audiences think. It contains both wit and wisdom; entertainment and insight. The play makes no apologies or assumptions. Written as fiction, it is still a kind of journalism, reporting on the state of a culture by telling the true stories of four divorced couples and their families. The play asks the elemental questions: What does it take to build a marriage? Why does a marriage fall apart? What implications does divorce have on the children? The script is crafted from telephone interviews that the playwrights conducted with their own divorced parents. These interviews are then recreated for the stage. What is rendered is hilarious, awkward and at times heartbreaking. Each of the characters is in his or her own space and does not interact with the other actors on stage. Yet, each character's story is intertwined with the others to reveal the common threads before and after divorce, from falling in love, having children, falling out of love, separation, and being single again.

I was given this script by Eve Theatre Company, a new theatre company in Louisville with the goal of opening doors in theatre to women. Eve Theatre posted an ad looking for a young female director and I applied. After meeting with me, the producers of the company asked 
me to direct Tales at the Slant Culture Theatre Festival. Eve Theatre told me they wanted to expand their brand. They did not want to be pigeonholed as a theatre attractive only to the over 50 crowd. Without alienating their loyal Baby Boomers they wanted to attract Generation Y (or the Millennials as they are often called). I found this honest and appealing. I was excited to work with them - and inspired to find a theater piece that would accomplish their goal. Tales from My Parent's Divorce seemed ideal. Generation Y would connect to the adult children exploring their parents' divorces, while the Boomers would connect to parents. To strengthen the bridge between the generations, I cast college students aged 21 to 30 , since that age range is commonly the point in one's life when marriage seems a promising possibility. The actors I chose also could draw on their own experiences in developing their respective characters. Today's statistics being what they are, each actor in the play had at least one divorced parent, though I did not require that.

This casting meant that each actor, while physically representing the children of divorce, would have to play the parents and convey their world weary tales of divorce. They resembled the children in terms of their age range but they had to take on the psychology of the divorced parent. In an age of technical and electronic wizardry, my staging tactic was much simpler than green screens and holograms. It's a device that served an essential tension in Tales from My Parent's Divorce: using casting to highlight the difference between the way the Baby Boom generation and Generation Y looks at divorce.

The Millennial generation is described as the New Frontier, changing the ideals and ways of their parents, the Baby Boomers. Millennials birth dates range from 1980s to early 2000s. They outnumber the generation previously thought of as the largest, Baby Boomers, by 11 million people (Raphelson). They are considered the most educated generation with 34 percent 
earning at least a bachelor's degree (PEW Research Center). According to PEW research study, Millennials are delaying marriage about 6.5 years longer than their 1960 s' predecessors. PEW also hypothesized that 25 percent of Millennials will not get married at all, based on how they ranked marriage as a passage into adulthood. What the research suggests is that Boomers' married readily but also divorced readily; Millennials marry more reluctantly but also divorce more reluctantly.

In mass media, divorce is treated as no more than another tantalizing celebrity tale, with the requisite subplots of who cheated on whom and who was paid what to walk away. The reality is that divorce is not a tabloid novelty. The reality is that many marriages end in divorce. I wanted to explore not the tabloid version of divorce but the more ordinary reality. I wanted to see what would happen if the Millennial generation took a long, hard look at the marital legacy left for us by Baby Boomers- whose marriages end in divorce as often as 50 percent (Miller). Tales brings both generations into one script to explore the roots of this cultural reality.

Given a powerful script designed to open a needed (but avoided) conversation between the generations, I wanted a directorial approach that served that imperative. I would not need lavish technology and special effects to stimulate the conversation. I would need to respect how vulnerable this piece and its characters could be. I would need to create characters and stories that would excite audiences used to million dollar explosions and 3D imaging technology. I was inspired as a director to find way to minimalize every barrier between the audience and the four actors - seated in chairs and without so much as a costume change - conveying these stories. If the actors could expose themselves to risk in the way this script demanded, with no gimmicks to hide behind, then I, as the director would expose myself to risk as well. I would embrace a simple goal to make the production special without use of special effects. I had to be unafraid, 
knowing that I would succeed, or fail, as a director on the strength of my ability to deliver a conversation about divorce that felt raw, real and pertinent

\section{About the performances}

The first three performances of my production of You Better Sit Down: Tales from My Parents' Divorce took place at the Slant Culture Theatre Festival, November 15, 21 and 22, 2014. This was the third year for the festival. Presented by Walden Theatre, Slant's intention is to provide a venue for uncommon works of theatre, each of which has a "slant" to them, or, that is, something defying convention used in theatre today.

I had a second chance to stage Tales in December, remounting it at the University of Louisville's Studio Theatre for three more performances. Studio Theatre is a free event presented by Theatre Arts students and open to the public. It is student-driven and provides student directors, performers, and technicians with opportunities that they may not get on the Main Stage during the Theatre Department's regular season. The U of L staging was especially important because the Slant dates conflicted with Freedom Days, a university production. Consequently, some of my faculty and classmates were unable to attend Tales on its first run. Studio Theatre gave them a chance to see my thesis project which was a culmination of my studies of the director's process at the university.

\section{Creating a Vision}

The role of the director is still relatively new to the theatre. The Duke of Saxe Meiningen of Germany is credited with being the first director. In 1866, he sought to find a role that would unify the conception, interpretation, and execution of dramatic works, and thus the role of director was created (Encyclopedia Britannica online). 
A director must be a "student" of the playwright, dissecting the material and interpreting its themes and ideas, bringing them to the stage with integrity and interpretation. A director begins by reading and analyzing the script, breaking it down into French scenes or motivational units. French scenes are defined by the moment when a character enters or exits the stage. Motivational units are the smallest units of a play where the motivation of a scene remains constant. Breaking down the larger picture of a play can help fine tune elements within each scene and help prepare a rehearsal schedule. For this rehearsal process, I chose to look at each scene indicated by the script individually, and worked with each actor on his or her arc and motivation units throughout the scene. I began my script analysis in April of 2014 when I first met with Eve Theatre Company to offer them my vision about this show. I then had to submit the script and a proposal to the Slant Culture Theatre Festival in June, complete with a full technical analysis, which for this show was relatively short. In August, I was accepted into the festival. I then looked again at the script and began breaking down the text and creating blocking.

According to the textbook, Play Direction by Dietrich and Duckwall, directing is not simply about creating emotion on stage, but eliciting it as well. Each character must be artfully crafted so that the audience can connect to the work on stage (46). This is done by projecting the characters' emotions in a way that the audience can understand. This can be done through visual cues such as blocking. Blocking is the term used to define designated movement on stage. I chose to keep my blocking simple, since the play title includes the words "You Better Sit Down", I wanted my characters sitting. I felt that their natural body positions and making them seem comfortable on stage was crucial to connecting the audience to the characters. Sitting gave me compatibility with the title as well as the simplicity I wanted and served the play's motif of conversation. But its sameness was also downside. Four actors seated for an hour risked 
monotony. To break that up, I added natural reasons for the actors to get up and exit the stage briefly. The space we used at the Slant Culture Theatre Festival was a black box theatre, with four entrances or exits available to the actors. I used each one as a specific character's "house", where they entered for the beginning of the play and would at times exit to refill a water glass, answer a call on a cell phone, or answer a doorbell.

This attempt to simulate a true human behavior is one of the most common struggles of a director. In some ways, theatre is supposed to be an illusion of life not a re-creation. Theatre on a stage, with a set and costumes, bending the laws of time and space can never be real. If a director simply hopes that "natural-ness" will make the production real, they will fail (Dietrich and Duckwall 48). Since theatre is the story of human conflict, the director must bring out the truth behind each movement and emotion in order to create the illusion of reality. If all goes as planned, the audience will suspend their disbelief and connect emotionally with the characters and the text-fitting what is on stage into the experience of their own lives.

The rehearsal process sets all the directors planning into motion. My rehearsal schedule was four days a week, throughout the month of October until opening in mid-November (see Appendix II). The first rehearsals are called table work, where we focus less on the movement and specifically on the text. This is when the actor and director get to talk about character approach and when most of the text analysis happens. We spent about three rehearsals at the table, dissecting and analyzing the script. We then moved into a rehearsal hall and began spending our time working on each section of the script. Rehearsals at times can be stagnant and in need of a refresh or new idea. I would often have my actors play games or give them new ways to say things, like screaming or whispering all their lines. These new approaches can breathe new life into the rehearsal process and help the director and actor make new discoveries. 
As opening night approaches, the director and cast begin technical rehearsals. These are designated times when all the technical elements, sets, props, costumes, lighting, and sound are added to the rehearsal process. Technical rehearsals allow the director to see all the elements together. They allow designers to make final adjustments and the actors to rehearse with all the elements just as they will be used during the run of the show. Technical rehearsals can be exhausting and time consuming, but by limiting technical elements the director and cast also save practical rehearsal time. The more complex the technical elements of the production the longer the technical rehearsals can be. For this production I had a total of four hours, broken down into two, two-hour blocks in the space, one seventh of the time spent in technical rehearsal at the University of Louisville alone.

After all the tweaks, fine-tuning and final touches, the production is finally set to open. Our opening night was Saturday, November 15, 2014 at 4:00 pm. Since the process of theatre is a creative one, no director, actor, or designer can be certain that the work will be a success. Come opening night, the production is now in the hands of the actors and audience to determine its success. The director's role throughout the run of the show is a "psychological one" (Dietrich and Duckwall 180). They must be a presence for the actors to help control excitement and tension. When the lights go down, the director's place is in the house, gaging the audience's reactions. I had the ability to watch my show each night, and each night had an audience with different reactions. To help in writing my thesis I asked for the audience members to fill out a survey, which I discuss in Chapter IV. 


\section{Chapter II: Eliminating Technical Elements}

HR Magazine calls Generation Y the "tethered generation" because it is the first to use emails, IM chatting, social media, and cell phones since childhood. While this connectivity has made access to information and people easier than ever, the Millennials might be getting trapped by technology — which from time to time fails. In 2006, Troilus and Cressida's premier performances at the Edinburg Theatre Festival had to be cancelled due to computer glitches. In 2014, the University of Louisville box office had to employ several scholarship students and volunteers to help write up tickets for the production of August Wilson's Gem of the Ocean because the box office computer shut down.

But technical glitches and the risks they bring are only half of the problem. It is the technological advancements of special effects that pose a threat to theatres live performance. In 1990, George Coates was considered a technological maverick by using video projection in his production of Architecture of Catastrophic Change (Gray). In 2004, set designer and winner of six Olivier awards, William Dudley, designed The Woman in White, which featured video projection on moving pieces of scenery (Shaw). In 2011, Robert Lepage brought 3D imaging technology without the need of eye wear to audiences the Metropolitan Opera in New York City (Wakin and Lohr). Pippin was revived on the London stages in 2012, but designed to look like the video game Tron, and featured media projections and avatar sword fighting (Shaw). And in 2012, Lemieux Pilon 4D made possible what all theatre technicians joke about. They created a stage filled with holograms. Lemieux's production of La Belle et Le Bête, only featured three real actors. The rest of the performers were holographic images alongside minimal physical set pieces and intricately laced holographic ones. While visually exciting and entertaining, replacing humans with holograms could lead to a scary reality, where the actor will no longer be vital to a 
stage performance. Soon after, the director will no longer be needed to breathe creativity and vitality into a script but rather will be given a joystick to move images across a screen. What theatre then will become is a hollow, holographic video game where one lone person could hold the controller, and instead of a director or stage manager the show could then be run by a video gamer or computer programmer.

While technology and technical elements can be a great tool, and all elements of theatre were new once, no matter what the technological state of our world, art should always be able to survive. International theatre critic, Harolde Wolfe warns that, "technology can serve as the replacement for imagination" (Gardner). He thinks we are losing touch with how theatre began and what it was originally created for: live performance.

Imagination is just what it took to strip away all the non-essentials. To envision a staging stripped of all but the simplest elements is a response to the explosion of special effects. But it also reflects another minimalist ethic to reduce the staging to all but the essential elements. Staging can be exaggerated even without technology. In 1912, David Belasco staged The Governors Lady at the Republic Theatre on Broadway. In the final scene of the performance Belasco recreated with near-perfect authenticity New York's Childs Cafeteria. Every detail down to the tiles, the menus, and the food were ordered from the same manufacturer used by the restaurant. The meticulous detail took time and commitment — time and commitment that can be saved when stripping away these unnecessary technical elements. In contrast, consider Robin Wagner's 1975 setting for A Chorus Line. It consisted of a white line on the floor and a black surround, only introducing an exclamation point of Mylar mirrors in the final scene. To arrive at that seemingly simple design took an enormous amount of work and thought, a process of stripping away all that was not essential (Aronson). This is what I tried for in Tales. 


\section{$\underline{\text { Process }}$}

The original production of You Better Sit Down: Tales from My Parents' Divorce was not elaborate. But it had its tricks. A white wall with a doorway on stage right led to what was decorated to look like a kitchen. The wall served as a projection screen. Character names and scene titles were projected on this wall. Also projected were a collection of images unique to each of the four actors, including wallpaper, family photos and home movies. One of the challenges in staging Tales is making sure that its rapid shifts from one character to the next remain coherent to the audience. One minute, an actor stage right may be speaking. The next, an actor stage left might be speaking. The projection of each actor's "home" was intended to guide the audience through these shifts.

Knowing that the original production was simple, but not without its own technical wizardry, my challenge was to see if I could strip it down even further and bring the story and the dialogue into even sharper relief. When I first read the script, I felt like the material relied too heavily on the projected materials. In the script, each scene title is projected above the actors' heads as if announcing a new chapter in a book. As the play continues, the script calls for the projection of character names and questions that were asked in the original interviews (e.g., “Where did you two meet?”). I felt that some of these could be eliminated completely and others, like the chapter titles, I replaced with voice over recordings of my actors reading each section heading. Those labels, as well as the wallpaper, movies and family photos, seemed a distraction to me, adding emotional distance between the actors and the audience. The more unique the character, the easier it might be to think of his or her story as specific to a particular cultural, racial or economic background. Each video or photograph would give those watching one more reason to experience the characters and the story less as universal and more individualized- more 
"them" and less "us." With minimalist techniques, I wanted to maximize the connection between the story and the audience.

The technical changes I had in mind for how I would produce Tales from My Parents' Divorce were ideal once I received the technical limitations of the Slant Culture Theatre Festival. The 50-person black box theatre only offered lights up and lights down via a slider switch on the wall and a mixing board that could hook up to two stereo speakers mounted on the wall. The walls and floors were black and I was provided with a corner to store my props and set pieces. A black box theatre is meant to be versatile and simple. The space inspired me to choose black as my main color palette, serving as a canvas on which those in the audience could paint their own stories. In the original production, each character had a different style chair designed to represent that family's home and to reflect the character's personality. I chose simple black chairs with a sleek silver outline that I pulled from what the university had in stock and had my actors dress in black shirts and jeans with minimal jewelry.

In this convention of minimalizing to maximize, my goal was neutrality. Neutrality in terms of this production is the space at its most basic; it has no defining features that suggest where the conversations are taking place or who specifically the characters are. By making the actors and the sets neutral, they became a canvas upon which each person could see parts of their own story. Technology distances us as a people. We look at our phones more than we look at each other's faces. We get easily distracted and easily bored. The arts should function on a more personal basis. You buy a ticket to be transported in to a world and to be entertained. In this show you cannot be transported if you are separated from the material it presents. Divorce is one of the most prevalent social phenomena today, yet it often gets overlooked, accepted, or turned into a farce. We never really look at divorce from the angle of the parent-child relationship. If 
one could not fully engage in the material on stage due to distractions or malfunctions, one would lose this valuable perspective.

Stripping down, or neutralizing, this production also makes it vulnerable. It is vulnerable in the sense that the material is exposed instead of obscured by the mise-en-scène. The actors are equally vulnerable, never given a chance to escape the audience's focus. The ability for a person to feel vulnerable is one of the most crucial elements when committing to a marriage. If you cannot be yourself in the most naked sense then you are always hiding behind something. If my actors or my audience had the opportunity to feel comforted and protected by superfluous technical elements, home movies, or even too much stage movement, they would be unable to fully realize the power that this show can have.

Since this piece was still considered a full production, and as Aronson suggests some technology can help connect to today's over stimulated audiences, I chose to keep three technical elements: props, lighting and sound. This decision to keep these elements was specific to their relative uses; I allowed each actor to have one prop to tell more about their character and give them something to use on stage. I used lights to help tell when the play started and ended and sound to move the story along. Since the script indicates relying on the projection to move the story further, I chose sound to mark passage of time and aid in the movement of the play. I do not consider sound a superfluous technical element because despite the incredible advancements we have made in that area of theatre, humans have used sound since theatre's inception. Music has roots in ritual performance and ceremonies from which theatre was derived. In the $16^{\text {th }}$ century Commedia dell'arte of Italy was one of the first known theatres to utilize sound effects (Wilson and Goldfarb 152). 
With the help of a sound designer, Alex Cooper, I created a playlist of music that would help denote the passage of time by choosing relevant and popular music from each decade of the play: the late 1960s for when the couples met, the 1970s for when they married, the 1980s for when things started to fall apart and the 1990s for after their divorces. Ms. Cooper and I combed through the top charts of those decades to find music that matched the mood and material of each section of the play (see Appendix III). We then used the set playlist for the show to create a preshow and post-show playlist.

When Ms. Cooper brought You Can Go Your Own Way by Fleetwood Mac to my attention, I immediately saw this song as central to my production of Tales from My Parents' Divorce. It is a breakup song with energy, not something easily found, plus its release in 1977 made it fit perfectly into our time table playlist. I loved the message of this song so I put it out of order and made it our curtain call song. Curtain call is the final bows for the actors. I like the song used for curtain call to have some energy. It can be a release for the actors who had to perform on stage, allowing them to step out of the character and enjoy their acclamations from the audience. This song served as an anthem not only for this show, but I think for the millions of divorced couples and their children wondering which path to take in life. The lyrics read:

\section{If I could}

Baby I'd give you my world

Open up

Everything's waiting for you

You can go your own way

Go your own way 
The message of this show serves two purposes: One, there is always another side to the story; and two, you do not have to be your parents. So while the song is inherently a break-up song ("You can call it another lonely day"), it can also serve as a reminder that children do not have to follow in their parents mistakes “everything's waiting for you / You can go your own way."

As discussed earlier, modern theatregoers expect to be entertained by spectacle. My challenge was to entertain without the spectacle. The actors, and the story, would have to capture my audiences. The shifting aesthetic would shift the focus solely to the actor. This challenge led to extensive character work, with rehearsals focused on moments in the play and the dynamics of each character on stage. The end result would need to be a tapestry of stories. Each character had his or her own story, but they had to be woven into one 


\section{Chapter III: Character Creation}

Drama at its roots is the story of human conflict. Therefore the director is required to not only look at the story given in the text, but to delve deeper than the surface value of the text and study the human being (Dietrich and Duckwall 3). Since the core of drama is the human, the director must study human conduct and how to make a human response credible and meaningful (4). I chose this approach to drama as my driving forces in creating Tales from My Parents' Divorce.

It is the work of the director with her characters that can make or break a show, especially a show without visual distractions. Since this show was going to be minimal in design, each actor would be the lone focus of his or her scene without even a scene change to provide them relief from the audience's attention. I wanted the audience to connect with these characters and their stories. Each character was given life, emotions not denoted by the script, and a natural body positioning to make each character human.

Due to the production's challenges, I had to cast actors who wanted to rise to the challenge. I held auditions in early September (see Appendix I), looking for three women and one man. I chose to have a woman play Janet, which was originally a male role ( a son playing his mother) per a request from Eve to help promote their "women in the theatre" initiative, and I felt Janet was the right character to be portrayed by a woman. I also wanted diversity, in order to reflect the racial and ethnic background of Louisville but also to give the play a more universal feel. Divorce isn't something that only happens to white Christians. This decision did not go unnoticed. In a review written by Arts-Louisville, they praised me for having "the most diverse 
cast in the [Slant Culture Theatre] festival" (Keel). Divorce affects all demographics, so why would I not showcase as many as I could?

\section{John/Frinde}

John and Frinde are the only characters who appear as a couple, through the actor who also portrays their son, Matthew. There are particular challenges a director must face when an actor must portray two people, both speaking, without costume changes, or minimal voice changes (as denoted by the script) and without hindering the movement of the script. I cast Crystian Wiltshire in the role, and from day one I was inspired to build this character. As we worked together, we came up with the idea for only John to wear glasses. Crystian would slide the glasses on and off his face to help create this distinction between when he was playing Frinde and when he was playing John.

Body positioning was the main way we created the difference in character for John and Frinde. Though originally very stiff, we worked on natural body positions for women versus men. Women cross their legs and ankles, they tend to sit more forward and talk with their hands. Men rest one crossed leg and tend to sit further back in their chairs and carry themselves as "high status characters." As Keith Johnstone lays out in his book Impro, "when a high status individual is most secure, they will sit in the most relaxed position"(59). I played around with this movement, and even asked the actor what positions he was most comfortable in. John is a confident comfortable character and paired with Frinde they can have their weak moments but throughout they are the most secure characters. I did not want John to have one position and Frinde to have another. They would stand out in the ensemble, looking stiff and limiting that actor of a natural whole performance. Another aspect of the John/ Frinde character that had to be 
created was voice. The script notes, "That despite male characters portraying their female mothers, they are not to adopt a 'female' voice." This was to avoid making a caricature of the mothers; instead, the intent was to keep them as natural and honest as their mothers were when being interviewed.

As rehearsals progressed, the movements became more natural, and the actor could seamlessly move from John to Frinde and back again. As with each character, I wanted to focus on how John and Frinde dealt with the more serious moments in their divorce, and how the earlier sections of the script lead up to that. During one rehearsal I made up a game to help my actors break through some difficulty they were having transitioning into the "How They Broke Up" section of the script. I wrote emotions up on the board: anger, betrayal, sarcastic, defensive, humorous, hurt, etc., and I told each actor to pick an emotion and perform that scene with that set emotion. They did this about four times until each one had found something new about their character. Each time they finished, I discussed with each person how that new emotion changed the way they looked at the material. Through this exercise, the cast and I made a breakthrough. We were able to begin that seamless transition into the harder parts of their characters' lives. It made them human, with a full character arc to work through during every performance. For John, we chose betrayal, since Frinde cheated on him several times; we also added in some moments of sarcasm since John alludes to having trouble expressing his true feelings and sometimes hides behind humor. For Frinde, the focus was guilt. She did betray John, and without this facet of her personality she seemed cold and unappreciative of her life with him. When we decided that Frinde would own up to her mistakes, we also figured out how John and Frinde could have such a peaceful resolution at the end of their marriage. 
For each character I wanted something that would, first, help them fill their time between monologues that seemed natural for someone to do while talking on the phone, and secondly, give the audience insight into that specific character. For John, I chose a coffee cup as a prop in addition to the glasses. The coffee cup is denoted in the script, and I thought paired with the glasses it would give him a sophisticated, more "Dad-like" touch.

\section{$\underline{\text { Beverly }}$}

Beverly is the character I loved to hate when reading the script. There are moments when she is speaking that I cannot believe how hard it must have been for her daughter to hear her say these things. Then, the moments I hated her for, became what made her character so rich and so real. I would be lying if someone did not gasp nearly every time they first heard Beverly say, "I do not remember anything at all to do with you. I am so blinded by myself, that the older I get the more I am realizing it is all about me and you are just a part of the picture." Or "Oh we never fought about that. We have always been like that, if you want the kids, you take them." Her unapologetic nature made her hard upon the first reading, but as all these characters were, I had to remember that she was human, and that hardness could have come from a repressed source. As the director it was my job to make the audience not loathe her, but to find some reasoning for her, to accept her inattentiveness to her children and also to open their eyes to someone in their real lives who may be feeling and acting the same way.

A particular challenge in choosing a diverse cast is that the director may be casting a different race from what was originally intended by the play's author. Beverly is written for an actress from a "working-class Jewish background" (14), and if cast as such, the text needs no adjustments. However, when this role is cast with someone of African descent, some lines take 
on new meaning. For example, on page 14, Beverly says "His background was YALE. My background was the street." Then again in reference to the March on Washington, Beverly brushes it off as if she does not remember it happening. I reworked those lines to sound more like she did not want to focus on it, not that she could not remember when it happened or what cause it was for. As the director, I wanted to avoid the "of course the mean wife from the 'street' is the Black one", I had to develop a deeper reason to why Beverly's marriage ended and why she could be so harsh. When you look at her character in the context of Beverly being a middle class white woman, the struggles of Beverly seem less important, shallower. It simply seems like she longed for a richer life and after their divorce her main concern was maintaining her accustomed lifestyle. If you then flip her character, making her a minority, her husband's pursuit of her and the conditions of the middle class minorities in the late 60s and 70s changes how an audience is likely to perceive Beverly.

Beverly's evolution began as we tried to find the source of her hardness. I wanted to know how someone could be so concerned only with themselves, but still be likeable or at least accepted by an audience. I told my actress, Dee Scott, to think about the possibility that Beverly could have been verbally and emotionally abused. She makes references in the text that her husband would call her names, and that he was her sole support, since he went to Yale and she was "from the streets." Once we started combing through Beverly's stories we found evidence that abuse could explain Beverly's hard edge and all at once Beverly came to life. We made her softer in parts, hurt and vulnerable, in contrast to her hardness and humor at other times. I asked people to sit in on rehearsals throughout my process. People told me they had a hard time connecting to Beverly. Once we found a source to her egoism, they saw her shift, they saw how beaten down she was and found reasons to forgive her selfishness. 
To support Beverly's character, I gave her a nail file as her prop. A nail file worked because Beverly is so concerned with appearances, that her constant primping helped sell to the audience that she was controlled by her selfishness, an outcome of what we believed was her abuse during her marriage.

\section{$\underline{\text { Mary Anne }}$}

Mary Anne was the character I had the most fun working on. Portrayed by Caroline Ruark, she was funny and honest. Mary Anne is the character who asks the question: "Does a marriage even need love?" Her character and story lend tremendous insight into what it takes to make a marriage successful and how ideals of the past lead to her divorce.

I chose to keep Mary Anne angry throughout the more serious moments of the script. Her husband left her alone to take care of the kids, barely talked to her and made her keep an OCDworthy clean house. I felt that a suppressed housewife mentality worked for her. She had to have some edge, almost as if Mary Anne had been forced her whole life to do everything right and this was the first time she was being honest. Her honesty paid off, it makes her more relatable. The audience can see that her feelings towards her ex-husband were justified. I also wanted Caroline to play with levels. At times, we had Mary Anne play very hard other times more vulnerable. Her humor helped the audience like her. Her vulnerability made the audience connect with her.

Mary Anne has a line in which she suggests she has been drinking tea throughout the show. I opted for Mary Anne to drink iced tea, to keep the props distinctive and not to be confused with John's coffee cup. It was natural and gave excuses for Mary Anne to leave the stage to refill her glass. 


\section{$\underline{\text { Janet }}$}

Janet is the character who surprised me the most. Her divorce story is different from the usual, and her evolution can be startling if you do not catch the hints she drops early in the text. I decided to try and stun the audience. I wanted Janet to have had a wonderful marriage to a man she thought she knew. Then the ball drops. He is in prison on fraud charges and has spent all of the family's money. Janet was played by Jennifer Siow and per request of my producers at Eve was the role I switched from originally a man playing himself and his mother to a woman playing her mother and the daughter. This only caused a few text revisions, changing "young boy" to "young girl" and a few pronouns from "he" to "she". Jennifer is of Chinese descent, this made the cast more diverse. Her ethnic background made no significant impacts on the script but on the tableau of the performance.

For Janet, I started with idea of "What if this was the first time Janet ever told this story to her child?" As the text indicates, her children were 11 and 16, a little young to grasp the severity of their father's crimes and their mother's decision to divorce him. Janet's strength as a character began to develop as we looked at new ways to approach her retelling of the first days after her husband, Chuck, was arrested. The emotion I chose for Jennifer to use was resentment. I wanted a contrast between the happiness and love she felt during the early years of her marriage and the hurt and anger she felt later. This made her character more complex and allowed the audience to hear a story about someone who did not necessarily want to get a divorce.

Janet's character prop was knitting needles. I always knew Janet would knit or sew on stage. It makes her seem like a little old lady who nothing ever bad happens to. It gave her 
innocence in contrast to her occasional harshness. Jennifer, who played Janet, could knit, and needlepoint felt too old-fashioned to me, so I chose knitting as her on stage activity. 


\section{Chapter IV: Gauging the Audience}

Once the production has opened, the work of the director is finished. There are no more notes to give, no more scenes to rework. It is the job of the director to enjoy the finished product and gauge the audiences' reactions. At all the productions I had to serve as the stage manager, calling the cues for lights and sound. However, since this was an easy show to run, I was still able to watch the audience throughout the production. Throughout each performance I looked for cellphones and body language. I wanted hints as to whether or not my audience was bored or looking for a distraction. I never did see someone pull out their cellphone, and luckily, none rang during the performances. I was excited by the interest I saw in my audience. I took it to mean that they were engaging in the material on stage.

Phenomenology is a psychological study of experiences and consciousness. This theory is often applied to theatre to help construct the experiences of the audiences, actors and director. "Phenomenology is not concerned with the world as it exits itself but with how the world appears to the humans who encounter it" (Fortier 38). This theory is also concerned with the way humans carry what has happened to them in the past, present and how that will shape their future (39). As theatregoers watch a production, their personal and cultural backgrounds influence the way they perceive a production. If an audience member comes from a divorced family or an actor's parents are currently getting a divorce that production will affect them differently from someone who has had not been significantly influenced by divorce. Phenomenology can also be applied to details of each performance such as where the audience sat: Could they hear? Were they tired?

Did the room smell different? All considerably minute details, but each according to phenomenology can affect the way an audience member perceives the performance. 
This concept of Phenomenology led me to create a survey for my audiences. The survey asked four questions (see Appendix V) about how this production furthered the discussion of marriage, a few demographic questions to help gauge their experiences with divorce and an "other comments" section. I wanted to keep the questions simple. Since my focus of my thesis is on how the limiting technical elements can enhance the way an audience perceives the material from the script, I focused my questions on whether or not this production made an audience member want to discuss divorce more openly. I was inspired by the original production's slogan "Join the Conversation," so I made that the measuring point for my audiences. I could hope that people after seeing this production rethink divorces or come to terms with divorce, but you cannot change people in one fell swoop. I wanted this play to be a starting point. That starting point would be talking about divorce, which then would hopefully open up more avenues of discussion and discovery. I chose to use the "other comments" section to see if audiences would say anything about the set or lack thereof. There were two mentions of the set, one liking it and the other wishing for an existence of one.

For the Slant Culture Theatre Festival, the survey was accessed via a QR code located on the program insert. I thought since QR codes are so popular today and easy to use, they would be the perfect way for the audience to access the survey. I was wrong. I had more than 110 people in my audience at the festival and only 11 responses. I was told that the QR code was hard to follow and according to the reviewer, Eli Keel from Arts-Louisville, the survey felt like an afterthought and showcased the "sharp reminder of the digital divide in theatre." I took this feedback and re-worked my survey for the University of Louisville performance in Studio Theatre into a printed version which audiences could fill out after the show. This gave me a much larger pool of about 70 responses to examine. 
Out of my responses, 60 percent of responders felt that Tales from My Parents' Divorce made them want to continue to further discuss marriage and divorce. No comments were left about the set or lack of technical elements. Some written responses included "It was very good", "Thought provoking and humorous; good stuff", and "The actors connected as the show progressed with their characters." Some more comical responses included "I don't ever want to get married" and "I am a kid so this show was so over my head".

When looking at the feedback I was provided, the production was more widely accepted at the Slant Culture Theatre Festival than at the University's Studio Theatre for two main reasons. Slant Culture attracts a more unique audience base. The slogan for the festival is "a laboratory for uncommon works" or "playful experiments $\rightarrow$ dramatic results". This environment called for "slanty" pieces of theatre. The festival directors wanted productions that would break the mold somehow. Audiences who bought tickets to the festival expected uncommon conventions for theatre, and even if audiences were not prepared for the lack of set or blocking in my production, they quickly accepted it as what made this production different. At the university, Studio Theatre is free and open to all. The majority of the audience is made up of fellow theatre arts students, many of whom, including myself, are on scholarship for technical theatre. I think our focus on the technical side of theatre makes students hyper aware of the production elements used in theatre. This awareness then can make a sparse production disappointing when there is a lack of production elements. The second reason I think the production was better received at the festival is the space. The black box at Walden Theatre where the festival was held is a converted classroom with enough space to hold a tightly seated 50 people. The audience sits on folding chairs, eye level with the actors on the stage and the front row is within arm's reach. This created a very intimate experience for both the audiences and the 
actors, which perhaps made the room feel fuller and superfluous technical elements would have overwhelmed the space. In contrast, the thrust stage where the Studio Theatre performance took place is much larger; it can seat more than 150 people and is about 30 feet long and 15 feet wide. I used black partitions to make the stage space smaller, but still the audience was distanced from the actors and the action on stage making the experience far less intimate on both sides of the actor-audience relationship.

The differences in experiences in the two spaces can be related to the theory of phenomenology, and is explained in the article The Phenomenology of Non-Theatre Sites of Audiences. In the article, the author, Newman, examines theatre done outside of the auditoriums which are “"reinforced by stage lighting, air-conditioning, protective arm-rests and an architectural emphasis on sightlines" (2). In his article he cites Mike Pearson, academic and director of site-specific company Brith Gof, as "phenomenological", where "the emphasis is on bodily contact, corporeality, and embodiment" (3). This physical relationship the audience had to the actors in the black box theatre at Slant Culture Festival allowed them to experience the production more through their senses rather than those who were separated and comforted by more structured thrust stage.

For me, this production did change the way I viewed divorce. I come from a family where divorce is rare, and those that did happen, happened long before I was born or old enough to know what was happening. I always thought of divorce as a failure or result of rushing into a union "not meant to be." This production and its process taught me that divorce can happen for many reasons, that there are always more sides to a story. It opened my mind to different ways of solving relationship problems and what kind of questions one might ask before entering a marriage. I now no longer think of divorce as a failure but as a result of something: 
miscommunications, lies or bad circumstances. I see that in some situations it takes tremendous courage to file for divorce and leave perhaps the only life you know. I credit this production with not only opening my mind but also my mouth so I too could join the conversation. 


\section{Chapter V: What Can We Take Away from This?}

Theatre began on a bare stage. But as new advances in intelligent lighting, sound capabilities, larger stages, and more tech-savvy audiences entered the theatre world, the art form shifted, even to the point that sometimes the show becomes an electronic device. The story can be lost, and with it theater's power and purpose to connect an audience to the themes, messages and insights found in a well-written, well-conceived script.

As Aronson discussed, technology can be used to change the way audiences perceive a performance. Just because they do not find the technology exorbitant does not mean it is not there. We live in an ever changing world. Theatre has survived the world's changes but the changes are speeding up. Consider that it took 335 years- from 1545 to 1880 - to progress from candles and torches to electric lighting. Coates was an innovator in 1990 with his video designs but by 2015- only 25 years later- theatre was able to incorporate holograms. When one considers the technological timeline, theatre could be an entirely new entity in the next 15 or 20 years. It is in that context that I decided to stage You Better Sit Down: Tales from My Parents' Divorce with a minimalist approach, testing whether, in with expectations of today's audiences, theater could still be special without special effects.

This project does bring up the question, does this idea of "making theatre special without special effects" work for all productions. The answer is no. Some shows require visually stunning frames, pyrotechnics, and more than a couple of special effects. It is hard to imagine Actors Theatre of Louisville's Dracula without pyrotechnics or trap doors. Think of Broadway's Wicked without magic or flying broomsticks. Theatre is an art form and those craftsmen and technicians who create such effects are artists. Their work should be admired and appreciated. 
But we as a society need to look at our art forms on either end of the spectrum; we cannot get caught up in everything modern technology has to offer. There are shows that can withstand malfunctioning modern technology or budget cuts. There are shows that need nothing other than a few actors on stage who have developed beautiful characters, who will speak beautifully crafted words and leave the audience better than when they found them. Consider the recent The Brother's Size by Tarell Alvin McCraney, performed at Actor's Theatre of Louisville in January 2015 with only three male actors and a salt ring around the stage. When performed in New York in 2007, The New York Times called it an “absorbing and emotionally resonant drama... It's the kind of performance that sweeps you away" (Zinoman 2007). This play deals with freedom and the struggles within and outside of the family for African Americans. Performances without many technical elements are required to have some greater purpose, they must reshape the way the audience approaches an issue, or reimagine the world they live in.

I wanted to show audiences that theatre can be special without special effects. The empty space when the set is sparse and there are little to no special effects can be filled by a relevant and meaningful script, by well-rehearsed actors, developed characters, by passion and creation. Tales from My Parents' Divorce gave me the opportunity to test this thesis, and my test was successful. This project taught me a lot more than just what it means to be a director. This project taught me how to solve problems, how to create a vision and gave me a new outlook on one of the most prominent social phenomena facing the world today. The skills I have developed throughout this process will help me as I transition from an academic setting into the professional world where I can continue to make theatre special without special effects. 


\section{Appendix}

I. Audition Form:

\section{Auditions!}

Louisville Slant Culture Festival and Eve Theatre Company Presents:

You Better Sit Down for This:

Tales from My Parent's Divorce

Directed by Anna Neikirk

Looking for: Three Women and One Male Character, age 18-30 all races and backgrounds welcome and encouraged!

When: Tuesday September 2, 2014 beginning at 8:00 pm

Where: Studio Arts Building, TA room 131

What: Please prepare a 60-90 second comedic monologue. You may be asked to read from provided slides.

If you have any questions do not hesitate to contact Anna Neikirk at 859.628 .4613 or akneik01@louisville.edu

- Show dates Are Saturday November 15, Sunday November 16, and Saturday November 22, with a possible performance on Sunday November 23. Remount will be December 4-7,2014

This show is part of the Louisville Slant Culture Festival, therefore if cast you will become an official Slant Participant. This show will also serve as my senior honors thesis and will be remounted in Studio Theatre. 


\section{Rehearsal Schedule}

October

\begin{tabular}{|c|c|c|c|c|c|c|}
\hline Sunday & Monday & Tuesday & Wednesday & Thursday & Friday & Saturday \\
\hline & & & $\begin{array}{l}1 \\
7: 30-10 \\
\text { Caroline at } \\
9\end{array}$ & $\begin{array}{l}2 \\
\text { OFF }\end{array}$ & $\begin{array}{l}3 \\
7: 30-10 \\
\text { Caroline } \\
\text { at } 9\end{array}$ & $\begin{array}{l}4 \\
\text { OFF }\end{array}$ \\
\hline $\begin{array}{l}5 \\
7-10 \\
\text { w/Caroline }\end{array}$ & $\begin{array}{l}6 \\
\text { OFF }\end{array}$ & $\begin{array}{l}7 \\
\text { OFF }\end{array}$ & $\begin{array}{l}8 \\
7: 30-10 \\
\text { Caroline at } \\
9 \\
\end{array}$ & $\begin{array}{l}9 \\
\text { OFF }\end{array}$ & $\begin{array}{l}10 \\
7: 30-10 \\
\text { No } \\
\text { Caroline } \\
\end{array}$ & $\begin{array}{l}11 \\
\text { OFF }\end{array}$ \\
\hline $\begin{array}{l}12 \\
12-2 \\
\text { w/ } \\
\text { Caroline }\end{array}$ & $\begin{array}{l}13 \\
7: 30-10 \\
\text { w/Caroline }\end{array}$ & $\begin{array}{l}14 \\
7: 30-10 \\
\text { w/Caroline }\end{array}$ & $\begin{array}{l}15 \\
7: 30-10 \\
\text { w/ Caroline }\end{array}$ & $\begin{array}{l}16 \\
\text { OFF }\end{array}$ & $\begin{array}{l}17 \\
\text { OFF }\end{array}$ & $\begin{array}{l}18 \\
12-3 \\
\text { No Jen }\end{array}$ \\
\hline $\begin{array}{l}19 \\
5-9 \\
\text { No Jen } \\
\text { w/Caroline }\end{array}$ & $\begin{array}{l}20 \\
7: 30-10 \\
\text { w/ } \\
\text { Caroline }\end{array}$ & $\begin{array}{l}21 \\
7: 30-10 \\
\text { w/ } \\
\text { Caroline }\end{array}$ & $\begin{array}{l}22 \\
7: 30-10 \\
\text { No Caroline }\end{array}$ & $\begin{array}{l}23 \\
\text { OFF }\end{array}$ & 24 TBA & $\begin{array}{l}25 \\
12-3\end{array}$ \\
\hline $\begin{array}{l}26 \\
5-9 \\
\text { w/Caroline }\end{array}$ & $\begin{array}{l}27 \\
7: 30-10 \\
\text { Everyone }\end{array}$ & $\begin{array}{l}28 \\
\text { OFF }\end{array}$ & $\begin{array}{l}29 \\
7: 30-10 \\
\text { Everyone }\end{array}$ & $\begin{array}{l}30 \\
\text { TBA }\end{array}$ & $\begin{array}{l}31 \\
\text { OFF }\end{array}$ & \\
\hline
\end{tabular}

\section{November}

\begin{tabular}{|l|l|l|l|l|l|l|}
\hline Sunday & Monday & Tuesday & Wednesday & Thursday & Friday & Saturday \\
\hline & & & & & & $\begin{array}{l}1 \\
5-7 \text { or 7-9 }\end{array}$ \\
\hline $\begin{array}{l}\text { TBA } \\
\text { TBA }\end{array}$ & $3: 30-10$ & $\begin{array}{l}4 \\
\text { TBA }\end{array}$ & $\begin{array}{l}5 \\
7: 30-10\end{array}$ & $\begin{array}{l}6 \\
\text { OFF }\end{array}$ & $\begin{array}{l}7 \\
7: 30- \\
10\end{array}$ & $\begin{array}{l}8 \\
2-5\end{array}$ \\
\hline $\begin{array}{l}\text { TBA } \\
\text { TBA }\end{array}$ & $\begin{array}{l}11 \\
\text { TBA }\end{array}$ & $\begin{array}{l}12 \\
\text { TBA }\end{array}$ & $\begin{array}{l}13 \\
\text { Festival } \\
\text { Opens } \\
\text { TBA }\end{array}$ & $\begin{array}{l}\text { No } \\
\text { Jenn } \\
\text { TBA }\end{array}$ & $\begin{array}{l}\text { Performance } \\
\text { at 4 } \\
\text { Call TBA }\end{array}$ \\
\hline $\begin{array}{l}16 \\
\text { Performance } \\
\text { at 7:30 } \\
\text { Call TBA }\end{array}$ & 17 & 18 & 19 & 20 & 21 & $\begin{array}{l}22 \\
\text { Performance } \\
\text { at 7:30 } \\
\text { Call TBA }\end{array}$ \\
\hline $\begin{array}{l}23 \\
\text { Festival } \\
\text { Closes }\end{array}$ & $\begin{array}{l}24 \\
\text { OFF }\end{array}$ & $\begin{array}{l}25 \\
\text { OFF }\end{array}$ & $\begin{array}{l}26 \\
\text { OFF }\end{array}$ & $\begin{array}{l}\text { Thanksgiving } \\
\text { OFF }\end{array}$ & $\begin{array}{l}28 \\
\text { OFF }\end{array}$ & $\begin{array}{l}29 \\
\text { OFF }\end{array}$ \\
\hline
\end{tabular}




\section{Song List}

Be My Baby_-The Ronettes (1979)

Chapel of Love-The Dixie Cups (1964)

Let's Stay Together-Al Green (1972)

Try A Little Tenderness-Otis Redding (1966)

How Can You Mend A Broken Heart_ Bee Gees (1971)

If you Leave-Orchestral Manoeuvers in The Dark (1986)

When You Were Mine-Prince (1980)

Go Your Own Way_Fleetwood Mac (1977)

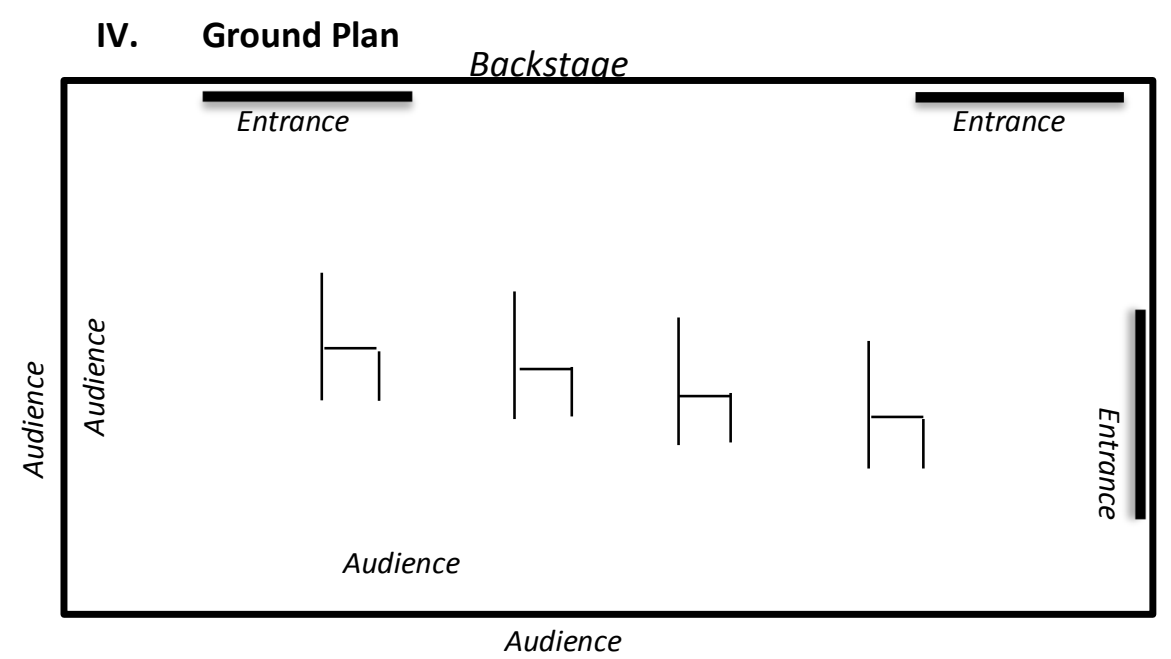

\section{Survey Questions}

1. "You Better Sit Down" made me want to further discuss marriage/divorce

Strongly Disagree Disagree Neither Disagree Nor Agree Agree Strongly Agree

2. I am an offspring of a divorced couple: Agree Disagree Declined to Answer

3. I am, have been, or will be divorced: Agree Disagree Declined to Answer

4. Additional comments about the show? 


\section{References}

"About/Contact." Slant Culture Theatre Festival. Walden Theatre, n.d. Web. 17 Feb. 2015.

Acaroglu, Gorkem. "Cyborg Prescence in Narrative Theatre." Australasian Drama Studies 65 (2014): 237+. ProQuest. Web. 12 Mar. 2015.

A, O. "A Tale of Four Budgets." DOLLARS AND CENTS A TALE OF FOUR BUDGETS (n.d.): 4859. National Arts Journalism Program. National Arts Journalism Program. Web.

Aronson, Arnold. "Theatre Technology and the Shifting Aesthetic." New England Tehatre Journal 8 (1997): 1-10. ProQuest. Web. 13 Mar. 2015.

Bell, L. A. J. "Between Ethics and Aesthetics: The Residual in Samuel Beckett's Minimalism." Journal of Beckett Studies 20.1 (2011): 32-53. Web.

Dietrich, John E., and Ralph W. Duckwall. Play Direction. Englewood Cliffs, NJ: Prentice-Hall, 1983. Print.

Flynn, Kevin, and Patrick Healy. "How the Numbers Add Up (Way Up) for 'Spider-Man'." The New York Times. The New York Times, 22 June 2011. Web. 19 Feb. 2015.

Fortier, Mark. "Theatre, Life and Language." Theory/theatre: An Introduction. London: Routledge, 2002. 56-60. Print.

Gardner, Lyn. "Modern Theatre Relies Too Much on Technology." The Guardian. The Guardian, 17 Apr. 2008. Web. 24 Dec. 2014.

Grotowski, Jerzy. Towards a Poor Theatre. New York: Simon and Schuster, 1968. Print.

Terry Hodgson, The Continuum Companion to Twentieth-Century Theatre, ed. Colin Chambers (London, 2002).

Johnstone, Keith. Impro: Improvisation and the Theatre. New York: Theatre Arts Book, 1979. Print.

Jones, Daniel. "From Spark to Hologram: A Timeline of Theatre Technology." ArtsEmerson Blog. Arts Emerson, 27 Nov. 2012. Web. 17 Dec. 2014.

Kauffman, Anne, Matthew Maher, Caitlin Miller, Jennifer R. Morris, Janice Paran, and Robbie Collier Sublett. You Better Sit Down: Tales from My Parents' Divorce. New York, NY: Dramatists Play Service, 2013. Print.

Keel, Eli. "Flawed Production Shines Light on Issues and Emerging Talent." Arts-Louisville. ArtsLouisville, 18 Nov. 2014. Web. 17 Dec. 2014.

Leff, Thomas. "Decor or Space: Architectural Stage Design and the Contemporary Theatre." Theatre Topics 1.1 (1991): 61-71. Web. 
"Meiningen Company | German Theatrical Troupe." Encyclopedia Britannica Online. Encyclopedia Britannica, n.d. Web. 28 Feb. 2015.

Miller, Claire Cain. "The Divorce Surge Is Over, but the Myth Lives On." The New York Times. The New York Times, 01 Dec. 2014. Web. 26 Mar. 2015.

Newman, Jo. "The Phenomenology of Non-Theatre Sites on Audiences." Theatre Notebook: A Journal of the History and Technique of the British Theatre 66.1 (2012): 48-60. ProQuest. Web. 12 Mar. 2015.

O'Neil, Melanie. "Lemieux Pilon 4D Presents 'La Belle Et Le Bete' with Arts Emerson." The Examiner. The Examiner, 06 Dec. 2012. Web.

Puchner, Martin. "Beckett/Albee (review)." Theatre Journal 56.2 (2004): 306-08. Porject Muse. Web. 12 Mar. 2015.

Raphelson, Samantha. "Amid The Stereotypes, Some Facts About Millennials." NPR. NPR, 18 Nov. 2014. Web. 15 Feb. 2015.

"The Rising Cost of Not Going to College." Pew Research Centers Social Demographic Trends Project RSS. Pew Research Center, 11 Feb. 2014. Web. 11 Feb. 2015.

Roessler, Norman. "Maria Stuart (review)." Theatre Journal 55.1 (2003): 150-51. Project Muse. Web. 12 Mar. 2015.

Shaw, Dougal. "Technology Transforming Theatre." BBC News. BBC News, 26 Mar. 2012. Web. 21 Jan. 2015.

"Spider-Man: Turn Off the Dark Takes Entertainment Technology to the next Level." PRG. PRG: The Production Resource Group, n.d. Web. 17 Mar. 2015.

"Touring Broadway Statistics." The Broadway League. The Broadway League, n.d. Web. 16 Mar. 2015.

Tyler, Kathryn. "The Tethered Generation." HR Magazine n.d.: n. pag. Print.

Wilson, Edwin, and Alvin Goldfarb. Living Theatre: History of the Theatre. 5th ed. Boston, MA: McGraw-Hill, 2008. Print.

"You Better Sit Down: Tales from My Parent's Divorce." The Civilians. The Civilians, n.d. Web. 17 Feb. 2015.

Xhonneux. "Rebecca Browns Evolution Towards Minimalism: A Beckettian Poetics." Literary Imagination (2013): n. pag. Oxford Journals. Web. 20 Mar. 2015.

Zinoman, Jason. "Two Brothers in a Gumbo of Bayou and West Africa." The New York Times. The New York Times, 19 Jan. 2007. Web. 17 Feb. 2015. 